$\mathrm{PhD}$ Želimir KEŠETOVIĆ*

University of Belgrade, Faculty of Security Studies, Serbia

$\mathrm{PhD}$ Višnja SAMARDŽIJA

Institute for Development and International Relations, Zagreb, Croatia Ivana SKAZLIĆ

Institute for Development and International Relations, Zagreb, Croatia

UDK $-327.7(282.243): 355.58$

Rewiew scientific paper

Received: 07.02.2015.

\title{
Sava Commission's role in improving security in South-Eastern Europe
}

\begin{abstract}
The International Sava River Basin Commission (ISBRC) or Sava Commission is an international organisation that has been established for the purpose of the implementation of the Framework Agreement on the Sava River Basin (FASRB) to reach the following goals: establishment of an international regime of navigation on the Sava River, establishment of sustainable water management and undertaking of measures to prevent or limit hazards and hazard related consequences, including those from floods, ice hazards, droughts and accidents involving hazardous substances. In the civil security area the ISRBC activities are mostly related to the information and data exchange between the Parties, including activities aimed at creating basis for implementing the EU Floods Directive.The area of the ISRBC work primarily includes prevention and preparedness aspects of the crisis cycle management.

Key words: The International Sava River Basin Commission, floods, emergency management, international cooperation, regional organization, civil security
\end{abstract}

\section{Introduction}

The paper aims to evaluate the role of ISRBC in improving regional security in South-Eastern Europe. It is the outcome of research carried out during the implementation of the ANVIL project, based on documents and

\footnotetext{
*E-mail: zelimir.kesetovic@gmail.com

** The research leading to these results has received funding from the European Union's Seventh Framework Programme FP7/2007-2013 under grant agreement ${ }^{\circ} 28467$. The authors would particularly like to thank to ISRBC Secretariat in Zagreb for useful inputs which were very helpful in conducting the research.
} 
reports on Sava Commission, the existing analytical papers and statistical data.

The Sava River Basin is a major drainage basin of South-Eastern Europe (SEE), shared by six countries and hosting a population of roughly 8.5 million. The Sava River Basin contains the largest complex of alluvial wetlands in the Danube Basin and large lowland forest complexes, being a unique example of a river basin with some of the floodplains still intact, thus supporting the flood alleviation and biodiversity. At the same time, it has a high potential for development activities, such as the waterway transport or tourism.

After the dissolution of SFR Yugoslavia in the early 1990s, the Sava River, which was the biggest national river, has become an international river of wider importance. The establishment of the Stability Pact for SouthEastern Europe in 1999 provided a basis for triggering cooperation of stakeholders in the region and, gradually, to the creation of a new approach to the water resources management in the Sava River Basin. The four countries of the Sava River Basin - Bosnia and Herzegovina, Federal Republic of Yugoslavia (later on Serbia and Montenegro, and then Republic of Serbia), Republic of Croatia and Republic of Slovenia, entered into negotiations to establish an appropriate framework for trans boundary cooperation, in order to ensure the sustainable use, protection and management of water resources in the Sava River Basin as well as to improve standards of living in the region. ${ }^{1}$

As a key milestone of the process, the Framework Agreement on the Sava River Basin (FASRB), was concluded as the first development-oriented multilateral agreement in the post conflict period after the Dayton Peace Agreement and the Agreement on Succession Issues. Three main goals of the cooperation within FASRB are i) establishment of an international regime of navigation on the Sava River and its navigable tributaries; ii)establishment of a sustainable water management in the Sava River Basin; iii) the prevention/limitation of hazards in the basin (i.e. floods, droughts, ice, and accidents) and elimination/reduction of related consequences.

To implement the FASRB, the International Sava River Basin Commission (ISRBC) was legally established as an international organization. Following the entry into force of the FASRB on December 29, 2004, the 1st Constitutional Session of the ISRBC was held on June 27, 2005, while the permanent Secretariat of the ISRBC started to work in January 2006.The ISRBC serves as a permanent working body responsible for the FASRB implementation, for the development of the Action Plan for Sava

\footnotetext{
${ }^{1}$ In the area of the Sava River Basin there have been no major disasters or crises so they were not among the main reasons for the establishing of the Sava Commission. See Section 2.4.
} 
River Basin and the adoption of the necessary legal documents and accompanying Protocols.

The Framework Agreement on the Sava River Basin (FASRB), representins a major legal instrument for cooperation. This Agreement also defines general principles on actions of the Parties and stipulates their cooperation and data exchange regarding water and navigation regime of the Sava River. Moreover, the Agreement provides regulations, organizational structures and administrative practices, and envisages mandatorycooperation with international organizations (namely, ICPDR, Danube Commission, UNECE, and EU institutions).The structure and the procedures of the ISRBC as well as its competences are stipulated in detail in Annex I to the FASRB, which serves as the Statute of the Sava Commission.

The legal role of the Sava Commission is twofold. According to the FASRB, it has the competence for decision-makingin the field of navigation, while it provides recommendationsin the field of water management. In the field of navigation, the Sava Commission decisions have a binding character for all Parties, and they have to be implemented in national legislation or implemented as the international regulations, which indicates a strong political will of the Parties to give such significant role to the Sava Commission in that field. Besides, the possibility of enabling the Sava Commission to make a binding decision on the level of protocols and agreements directly, in relevant area of water management, is currently under examination $^{2}$ (Samardžija, Skazlić, and Kešetović, 2013).

\section{Sava Commission activities related to civil security}

The ISRBC civil security activities are primarily related to environmental threats, including the prevention of floods, droughts and ice hazards, as well as accidents involving substances hazardous to water and reduction of their negative consequences. No prioritization is made among the listed threats.

Given that the Sava Commission is the first international/transboundary system for cooperation in its issue area, the Sava Commission activities are mostly related to theinformation exchange and data collection as well as to activities aimed at creating and preparing the basis for implementing the EU Floods Directive. In contrast, the Sava Commission does not have any operational role in crisis management. So far, the Sava Commission activities in the area of civil security i.e. flood management, accident prevention and control etc., are primarily focused on prevention and

\footnotetext{
${ }^{2}$ So, the state of art is that there are two kinds of decisions: binding in the field of navigation and non-binding (recommendations) in the field of water management.
} 
preparedness aspects of the crisis cycle management. This includes establishment of the Geographical Information System (GIS) ${ }^{3}$, establishment of hydro meteorological data and information exchange system, the development of integrated systems for floods forecasting and early warning, and development of the Plan for crisis management in the events of water pollution (Samardžija, Skazlić, and Kešetović, 2013).

Furthermore, the Parties are already connected through the Accident Emergency Warning System (AEWS), including the Danube Basin Alarm Model (DBAM) and alarming/alerting mechanism connecting the civil protection institutions (principal alert centres - PIAC)- developed in the framework of the ICPDR. Currently, the PIAC centres work permanently (24/7) in Slovenia and Croatia, while in Bosnia and Herzegovina and Serbia they are still under development. The existing structures in the Parties are regularly testing by the PIAC's staff, in order to assess their preparedness and response to the emergency situations. It is expected from the ISRBC to take a leading role in monitoring the results of the tests and in organizing trainings to increase the operational capacities of the PIACs (ISRBC, 2011).

Improvements of existing activities related to the prevention and preparedness, as well as introduction of the activities related to crisis response are foreseen in additional protocols to FASRB (namely, the Protocol on flood protection to the FASRB and the Protocol on emergency situations to the FASRB). These Protocols have been created in order to provide and define specific roles of Sava Commission and the national institutions of the Parties in the events of crisis. Upon ratification, they will become a legal base for effective and coordinated actions (ISRBC, 2011; ISRBC, 2012). In this regard, the real impact of the Sava Commission on civil security provision will emerge in the future. However, the envisaged strengthening of the Sava Commission does not change the main emphasis on national institutions of the Parties and their joint action.

All ISBRC activities are performed by civilian staff. Cooperation with the institutions of the Parties responsible for the FASRB implementation as well as with other national institutions i.e. agencies, offices, services, institutes and universities, has been established and maintained. Given the fact that the Sava Commission does not have any operational role in crisis

\footnotetext{
${ }^{3}$ The objectives of the Sava GIS are to provide coherent, timely, and open access to integrated data, information, services and tools with sufficient accuracy and precision to the water resources planners and decision makers in order to address important water management issues in the Sava River Basin (see more: Geographic Information Strategy for the Sava River Basin 2007-2012, available at:

http://www.savacommission.org/dms/docs/dokumenti/documents_publications/strategies/sava _gis_strategy/sava_gis_strategy_final.pdf)
} 
management, this organization does not have its own assets for responding to a crisis nor use members' civilian and/or military assets.

The Sava Commission has a cohesive character. Through its activities, the Sava Commission contributes to the efficient approach of the MS regarding a certain challenge and successful implementation of joint projects (currently, the project for the protection and rescue in accidents is being planned). The Sava Commission is primarily a platform for sharing information, reporting and capacity building of member states (organizing of the PIAC staff training).

The ISRBC can be seen to have incorporated lessons learned. Generally, the FASRB has proven to be a good platform for cooperation improvement among Parties by intensifying their contacts, providing opportunities for good practice exchange and additional trainings of representatives working in the ISRBC expert groups as well as improvement of inter-sectorial cooperation. However, lack of human and financial resources of the Parties, especially difficulties in securing financial instruments for implementation of the priority projects, remain the main obstacles in the FASRB implementation. The additional challenge is a limited access to basic data (hydrologic, topographic etc.) necessary for ISBRC studies preparation, especially when these data belong to the institutions not officially nominated for the FASRB implementation. There are also difficulties related to the specific fields of the FASRB implementation, especially different perception of water management and related requirements among representatives from the Parties (ISRBC, 2011, pp. 14, $15)$.

Further improvement of the FASRB implementation would include: to raise awareness of existing cooperation of the Parties within the FASRB, to ensure adequate human and financial resources to follow up activities coordinated by the ISRBC, to provide additional funds for realization of ISRBC respective activities and projects, to facilitate access to relevant data needed for ISRBC studies preparation, etc. Further strengthening of the capacity within the ISRBC framework (i.e. stronger support to the ISRBC expert groups) and the capacity of the ISRBC Secretariat has also been called for (ISRBC, 2011, pp. 14, 15). Finally, strong flods in spring 2014 led the participating countries to start rethinking the possibilitiy of giving the ISRBC higher competences. In the first place, this includesthe ratification of the Protocol on flood protection to the FASRB. The realization of the activities envisaged by this Protocol will contribute to the minimization of the flood risks and their negative consequences in the future. The ISRBC Parties have acknowledged the importance of the Protocol and have already startedwith implementation ofits activities within the Sava Commission, not waiting for the Protocol to enter into force. In this regard, drafting of the Flood Risk 
Management Plan as well as the development of the hydrological and hydraulic model for Sava River Basin has already started. Moreover, the Sava Commission has submitted the project proposal to the Investment Framework for Western Balkan which will support all other activities related to the development of the Plan as well as the activities related to the forecasting, warning and alarming (http://www.lijepanasasava.hr/vijesti/ 2014/06/24/savskoj-komisiji-drzave-savskoga-slijeva-zele-dodijeliti-veceovlasti/).

\section{The assessment of the role of the ISRBC - the quality issue}

The Sava Commission activities in the area of crisis management are primarily focused on prevention and preparedness ${ }^{4}$ for crisis situation that might happen in the Sava River Basin, first of all floods, water pollution and different kind of chemical, transport and other accidents etc. Most important activities related to crisis prevention refer to Program for development of the Flood Risk Management Plan in the Sava River Basin, including flood risk assessment, flood forecasting, flood maps, warning and alarm system; exchange of information significant for sustainable flood protection, and implementation of all measures and activities of mutual interest originating from planning documents or activities, standardization of equipment of port facilities, implementation of provisions on prevention, control and reduction of water pollution from shipping, transboundary cooperation etc.

Most of the realized activities in the field of crisis management refer to preparatory activities like analysis of existing regulations in Member States (i.e. Water law), institutional organizations (i.e. organizations responsible for implementation of accident prevention, PIACs, authorized companies to remove pollution) and the existing data about protection plans, pollution sources, authorized laboratories, etc. This was a necessary prerequisite for the preparation of the Protocol on emergency situations as the legal framework for all crisis management related activities. ${ }^{5}$ The Draft

\footnotetext{
${ }^{4}$ In the draft Protocol on Emergency Situations envisages also cooperation among the Parties concerning the mutual assistance, exchange of information, exchange of technology and research and development, related to the prevention of, preparedness for and response to such accidents

${ }^{5}$ The provisions of the Protocol refer to extraordinary impacts on the water, water regime and water eco-system and it obliges the parties to establish a coordinated or joint system of measures, activities, warnings and alarms in the Sava river basin. It defines the system of emergency prevention, preparedness, response and mutual assistance in case of extraordinary impacts. It also describes the rights of the public for access to information, public participation and access to justice. Each Party shall establish institutional arrangements and cooperation to exchange data, technology and research and develop methods and technologies for the prevention, preparedness and response to accidents.
} 
Protocol on emergency situations was adopted by the ISRBC in March 2009 and distributed to the Parties for final review. Final harmonization is expected, depending on readiness of the Parties.

Activities related to the Accident Early Warning System- AEWS were focused on improvements and modification of the integrated system to exchange warning, data and information about the accident and a review of the operative structure and capacities within relevant bodies. Consideration of possibilities for unification of different systems for accident prevention and control (e.g. AEWS, CECIS (EU), UNECE system) was also initiated by the Expert Group in 2011. In this context, activities of the ICPDR and UNECE are being monitored.

The AEWS is tested regularly. The tests have confirmed that the system is working as expected from a technical point of view, but on the other hand it is obvious that the operative structure in the countries would need further improvements. At present, the PIAC centres operate 24 hours a day only in Croatia and Slovenia. This fact might cause problems in case of accidents which happen in reality. In the future, major steps should be initiated towards the operational functionality of the PIAC centres in the countries, especially in Bosnia and Herzegovina and Serbia. ${ }^{6}$

Following the analysis of results of the tests, performed -within the framework of the Permanent Expert Group for Accident Prevention and Control (PEG APC), training courses for operational staff of the PIACs were organized in cooperation with the ICPDR to increase the capacity of the PIAC's staff in the Parties in 2009 and 2010.

In the hot phase of crisis exchange of information and mutual assistance are provided by protocols. According to bilateral agreements between Member States there is possibility of mutual cooperation outside the framework of the Sava Commission. In most cases, the Sava Commission and representatives are familiar with or even invited to attend these activities (Samardžija, Skazlić, and Kešetović, 2013).

In certain cases formal mechanisms are by-passed informally. Thanks to personal relationships and experience of working together in the Sava Commission in 2010 when there was a big flood on the river Bosut in Croatia, activities have been undertaken by Serbia on their portion of the

\footnotetext{
${ }^{6}$ PIACs in Slovenia and Croatia are a part of the whole system of civil and emergency protection system and they operate 24/7. In Serbia and Bosnia \& Herzegovina, PIACs have been established but they have not yet been incorporated in the structures which enable early warning and effective response in case of emergency situations causing or threatening to cause negative impact to water regime and aquatic eco-system. Legal system and national authorities in those two countries have not been developed yet to enable the incorporation of the existing PIACs into the emergency warning and response system. This is one of the main objectives of the ISRBC to be accomplished in the following period initial inventory of the flood management.
} 
same river, facilitating the flood alleviation in Croatia(Samardžija, Skazlić, and Kešetović, 2013).

To enhance the cooperation of the Parties in the emergency situations which have or could have impact to water and aquatic eco-system, aroundtable on Accident Prevention and Control was organized (Zagreb, October 21, 2010), and roundtable on the Draft Protocol on Transboundary Impacts to the FASRB (Zagreb, March 6, 2012).

When it comes to flood protection, main activities have beenfocused on the preparation of the Sava River Basin Flood Risk Management Plan in accordance with the EU Flood Directive and the development and upgrade of hydro-meteorological information and flood forecasting and early warning system for the Sava River Basin.

The Protocol on Flood protection to the FASRB, the basic document defining the cooperation of the Parties in the field of flood management, has been finalized and signed by the Parties in June 2010. As the $2^{\text {nd }}$ Meeting of the Parties to the FASRB (Belgrade, June 1, 2009) encouraged continuation of already started joint actions in the field of flood management before formal ratification of the Protocol, the ISRBCstarted with preparation of the Program for development of the Sava FRM Plan, through a project financed by the $\mathrm{UNECE}^{7}$, along with initial flood vulnerability assessment and the assessment of potential climate change impact on flood management in the Basin.

The cooperative effort of the US Army Corps of Engineers (USACE) and the ISRBC and national institutions of the Parties has been continued and resulted in the development of a hydrologic model for the whole Sava River Basin and a single shared hydraulic model of the entire Sava River. These products are the first georeferenced models ever produced for the whole area and, as such, represent a good basis for various needs of the Parties to the FASRB. The models will be shared between the member countries, with the intention to update information as it becomes available, and have potential to be used to prepare the flood mapping, support the flood forecasting system, and for alternatives analyses of future flood protection projects. Successful development of the joint models will have a direct impact on international efforts to develop integrated flood hazard and risk maps, integrated data collection, flood forecasting, and flood warning systems, which will reduce vulnerability to natural, technological, andsocial hazards. As these models can be regarded as preliminary, an additional effort is required to accommodate their functional use to the above mentioned purposes. Additional hydrologic and better geometry data are required from the Parties

\footnotetext{
${ }^{7}$ Building the link between flood risk management planning and climate change assessment in the Sava River Basin
} 
for calibration and verification of the models. Steps toward ensuring continuation of cooperation with the USACE have already been taken.

A comprehensive database has been compiled by the Secretariat of the ISRBC, based on the raw data submitted by the Parties. The database consists of more than 3300 georeferenced cross-sections of the Sava River and its several major tributaries and canals. In addition to this main achievement, various received data (on levees, storage areas, bridges, etc.) have been compiled into a GIS form. Those sets of data represent a strong basis, not only for planned flood-related activities, but also for other activities of the ISRBC and the Parties in RBM, navigation, water quality modelling, etc.

Having in mind the nature of almost all realized Sava Commission activities in the field of crisis management - preparing the protocols, standards, plans, risk assessment and so on, and that the three main protocols in this area are still not in force, at the moment it is very hard to assess its results in terms of effectiveness. When the protocols on flood protection, on prevention of water pollution caused by navigation and on emergency situations come into force and start to be implemented it will be possible to evaluate their effects. However, it is sure that all undertaken activities gave significant contribution to the successful risk management in the Sava River Basin, increased resilience and the overall capacity of the member states to respond to various emergency situations that may occur on the Sava River and its main tributaries (ISRBC, 2011).

There has been no particular review/evaluation of Sava Commission by participating Member States, except regular monitoring already described in this paper However, it should be mentioned that the $3{ }^{\text {rd }}$ Meeting of the Parties, attended by high officials of the four countries, as well as representatives of international institutions and organizations, served as an excellent opportunity to review the results achieved by the ISRBC since the previous meeting (June 2009). The Meeting clearly showed that the FASRB represents a good basis for further development and intensification of cooperation in the region, as well as further improvement of cooperation among the national institutions of the Parties, especially using the mechanisms of, and the activities performed through, the ISRBC. Also, the ISRBC is recognized by international partners as an important regional player and a solid ground for a good cooperation, and providing synergies in the cooperation, with other international organizations and institutions (ISRBC, 2012).

The fact that the legal and institutional ambience of the Partiesis different, and that institutional and legal system of two countries - Serbia and Bosnia and Herzegovina is not harmonized with Acquiscommunautaire is, tocertain extent, an obstacle to improving efficiency. 


\section{Conclusion}

Currently, the ISRBC does not have any operational role regarding crisis management and its activities are still mostly related to the prevention and preparedness aspects e.g. the analysis of the existing situation, information and data collection. Thus, the GIS system was established as well as the hydro meteorological data and information exchange system. Furthermore, the integrated systems for flood forecasting and the Plan for crisis management in the events of water pollution were developed. In order to provide and define specific roles of ISRBC and national institutions of the Parties in the events of crisis, additional protocols to the FASRB have been created (Protocol on flood protection to FASRB and the draft Protocol on emergency situations to FASRB). Upon ratification, they will become a legal base for effective and coordinated actions in emergencies. Thus the real impact of the ISRBC is expected to be proven in upcoming period, even if it does not question the main responsibility of national institutions of the Parties and their joint action.

The ISRBC cooperates with a large number of international organizations, especially with the International Commission for Protection of Danube River (ICPDR), the Danube Commission, the United Nations Economic Commission for Europe (UN/ECE) and institutions of the European Union. Although the ISRBC enjoys a significantEU support (mostly related to the financing of its projects) their relations are still not officially formalized and EU is also not an observer in the Sava Commission.

Although the Parties are committed to the cooperation within ISRBC and have achieved initial results, there is still a plenty of room for further improvement in all fields of cooperation, and particularly in civil security matters. Actually, in the field of crisis management, almost all realized Sava Commission activities were preparatory activities, i.e. preparing the protocols, standards, plans, etc., while the main protocols in this area are still not in force.

Existing progress in the field of water management, where requirements are based on recommendations and conclusions of the ISRBC, is partly affected by a different perception of these requirements by the competent authorities of the Parties. In some Parties additional obstacles include lack of appropriate institutional arrangements and lack of harmonization of the legislation with the EU Acquiscommunautaire.

There is no doubt that Sava Commission has become one of the first (not numerous) respectable international organisations in post-conflict area of South Eastern Europe. Its achieved results in the fields of navigation and water management have significantly enhanced the state in the area. When it comes to water management and other crises situation related to the Sava 
Basinthemore tangibleresults can be expected in the future. Experiences until today as well as improvements of the Members States in the process of European integration give basis to conclude that the Sava Commission will have success in this area.

As regards to the FASRB implementation, major obstacles and difficulties are associated with lack of human and financial resources of the Parties for implementation of the priority projects. Despite the fact that external financing of a number of projects has been achieved, the needs are far beyond possibilities, particularly having in mind the major flood accidents in spring 2014.

\section{References}

1. Geographic Information Strategy for the Sava River Basin 20072012, Available at:http://www.savacommission.org/dms/docs/dokumenti/documents publications/strategies/sava_gis_strategy/sava_gis_strategy_final.pdf [Accessed 4 January 2013]

2. ISRBC (2002) Framework Agreement on the Sava River Basin (FASRB), Available at: $<$ http://www.savacommission.org/dms/docs/dokumenti/documents publications/basic_documents/fasrb.pdf $>$ [Accessed 4 January 2013]

3. ISRBC (2005) Main functions, Structure of the Secretariat and Job Description, Available at: $<$ http://www.savacommission.org/dms/docs/dokumenti/documents _publications/basic_documents/main_functions_structure_of_the_sec retariat and job_description.pdf $>$ [Accessed 16 December 2013]

4. ISRBC, (2008).Expert Groups. [online] (updated 24 July 2008) Available at: $<$ http://www.savacommission.org/organ/3 $>$ [Accessed 22 March 2013]

5. ISRBC, (2008).Functioning. [online] (updated 12 December 2008) Available at: <http://www.savacommission.org/functioning > [Accessed 22 March 2013]

6. ISRBC, (2008).Secretariat. [online] Available at: $<$ http://www.savacommission.org/organ/2 $>$ [Accessed 22 March 2013]

7. ISRBC (2010) Protocol on Flood Protection to the FASRB, Available at: $<$ http://www.savacommission.org/dms/docs/dokumenti/documents _publications/basic_documents/protocols/protocol_on_flood_protecti on_to_the_fasrb_final_for_signing.pdf $>$ [Accessed 4 January 2013] 
8. ISRBC (2011) Action Plan of the Strategy on Implementation of the FASRB for the period 2011-2015, Available at: $<$ :

http://www.savacommission.org/dms/docs/dokumenti/sastanci_stran a/3._sastanak_strana_fasrb/action_plan_for_the_period_20112015.pdf $>$ [Accessed 4 January 2013 ]

9. ISRBC (2012) Annual Report on Work and Activities of the ISRBC for the Period April 1, 2011 - March 31, 2012, , Available at: $<$ http://www.savacommission.org/dms/docs/dokumenti/annual_rep orts/2011/annual_report_2011_final_eng.pdf $>$ [Accessed 4 January 2013 ]

10. Interview, ISRBC, Zagreb, February 2013

11. ISRBC (2013) Annual Report on Work and Activities of the ISRBC for the Period April 1, 2012 - March 31, 2013, Available at:

http://www.savacommission.org/dms/docs/dokumenti/annual_reports /2012/annual_report_2012_final-hrv.pdf [Accessed 16

December2013 ]

12. Samardžija, V., Skazlić, I. and Kešetović, Ž. (2013).ANVIL Regional organization study: The International Sava River Basin Commission ISRBC available on www.anvil-project.net

\section{Улога Савске комисије у унапређивању безбедности у југоисточној Европи}

Anстракт: Међунарона комисија за слив реке Саве (The International Sava River Basin Commission - ISBRC) или Савска комисија представља међународну организаиију која је основана ради спровођева Оквирног споразума о сливу реке Саве (the Framework Agreement on the Sava River Basin - FASRB) како би се постигли следећи ииљеви: успостављање међународног режима пловидбе реком Савом, успостављање одржсиог управљања водама и предузимање мера за спречавање опасности и юихових последица, укључујући опсности од поплаве, леда, суше и акиидената са опасним материјама. У области цивилне безбедности, активности Савске комисије углавном су везане за размену информаиија и података између земаља потписница, укључујући и активности на стварању основе за примену Директиве ЕУ о поплавама. Делатност Комисије углавном је везана за превентивне и припремне аспекте кризног менаимента.

Кључне речи: Међународна комисија за слив реке Саве, поплаве, управљање у ванредним ситуачијама, међународна сарадња, регионална организачија, ичивилна безбедност 